\title{
APRESENTAÇÃO DA CONFERÊNCIA DE GERT GRÖNING
}

\author{
João Carlos NUCCl ${ }^{1}$
}

O trabalho a seguir é de autoria de Gert Gröning, professor do Instituto para História e Teoria do Design da Universidade das Artes de Berlim em Berlim (Alemanha) e trata-se de uma conferência proferida no VIII Congresso Brasileiro de Arborização Urbana em São Paulo/SP (Brasil), ocorrido entre os dias 13 e 18 de setembro de 2004.

O Prof. Dr. Gert Gröning coloca-se como pesquisador na área da "Cultura do Jardim e Desenvolvimento de Espaços Livres". Seus trabalhos, muito conhecidos em grande parte do mundo, vêm alcançando uma maior penetração no Brasil, principalmente após o ano 2000, com sua participação no I Fórum de Debates Ecologia da Paisagem e Planejamento Ambiental, realizado em Rio Claro/SP, a convite do Prof. Dr. Felisberto Cavalheiro².

Em 2003 e 2004, Gröning retornou ao Brasil para participar dos Congressos Brasileiros de Arborização Urbana, em Belém/PA e em São Paulo/SP respectivamente.

Em sua conferência, transformada no artigo que se segue, Gröning deixa transparecer claramente seu receio em relação a certo "ponto de vista ecológico" como também ao "planejamento da paisagem", enfatizando que "o desprezo dos aspectos sociais, econômicos e políticos do desenvolvimento humano é um erro cardeal deste assim chamado ponto de vista ecológico" e que "o planejamento da paisagem na Alemanha ainda não conseguiu claramente afastar-se de tais inclinações Nacionais Socialistas".

Essa colocação serve de alerta para os pesquisadores no Brasil, pois ao se importar paradigmas de outros países, sejam eles da área da Ecologia ou do Planejamento da Paisagem, deve-se ter em mente que sempre haverá ideologias acopladas.

Gröning pensa que seria mais significativo para o desenvolvimento da civilização verificar democraticamente como diferentes grupos de uma sociedade se apropria e domina a natureza e assim caminhos se abririam em direção a uma teoria como parte do debate da cultura do jardim e do desenvolvimento dos espaços livres no mundo em urbanização do século XXI. O autor acredita que a cultura do jardim e do desenvolvimento dos espaços livres pode participar do contínuo processo de civilização e urbanização em um estado democraticamente constituído, entendendo também que essas questões fazem parte de um caminho para a democracia.

${ }^{1}$ Professor Doutor Adjunto do Departamento de Geografia da UFPR

2 Felisberto Cavalheiro (1945-2003) foi, desde 1988, professor do Departamento de Geografia da Faculdade de Filosofia, Letras e Ciências Humanas (FFLCH), da Universidade de São Paulo (USP). Em 1967 graduou-se em Agronomia na Escola Superior de Agricultura "Luiz de Queiroz" da USP em Piracicaba/SP e, depois de formado, atuou junto a órgãos públicos em Brasília e em São Paulo na área de Manejo e Gestão do verde urbano, trabalhando com parques urbanos, jardins e arborização. Concluiu em 1981 o seu doutoramento na área de Paisagismo na Fach-bereich Landespflege, Universidade de Hannover (Alemanha), com a tese "Die kommunale Freiraumverwaltung in São Paulo, Brasilien: Gegenwärtige Situation und Chancen zukünftiger Entwicklung" (Administração Municipal de Espaços Livres em São Paulo, Brasil: situação atual e opções para futuro desenvolvimento), sob a orientação do Prof. Dr. Gert Gröning. Em 1992 retornou, subvencionado pela Sociedade Carl Duisberg (CDG), à Alemanha para fazer seu pós-doutoramento. Era fluente na língua alemã, e mantendo seus contatos desde os tempos de doutoramento, era um dos elos de ligação entre a Geografia brasileira e a Geografia alemã. Em mais de uma oportunidade, trouxe seu orientador, Prof. Dr. Gert Gröning, para ministrar palestras no Brasil. 
- A conferência ministrada em 2004 (São Paulo/SP) esteve acompanhada por 38 slides no programa Power Point que foram gentilmente cedidos por Gröning para a RA'EGA. Entretanto, só foi possível a publicação de parte dessa coleção de imagens.

A RA'EGA agradece ao professor Gert Gröning por permitir a publicação de sua conferência bem como das imagens apresentadas na ocasião.

Os créditos da tradução para a língua portuguesa do original, em sua maior constituição em língua inglesa e parte em língua alemã, são do Arquiteto e Mestre Paulo Celso Dornelles Del Picchia, a quem a RA'EGA também agradece pelo excelente trabalho. 